\title{
Blind dating - mate finding in planktonic copepods. I. Tracking the pheromone trail of Centropages typicus
}

\author{
Espen Bagøien ${ }^{1,2, *}$, Thomas Kiørboe ${ }^{1}$ \\ ${ }^{1}$ Danish Institute for Fisheries Research, Department of Marine Ecology and Aquaculture, Kavalergården 6, \\ 2920 Charlottenlund, Denmark \\ ${ }^{2}$ Present address: Department of Biology, University of Oslo, PO Box 1066 Blindern, 0316 Oslo, Norway
}

\begin{abstract}
Mate-finding behaviour in the marine copepod Centropages typicus was investigated by 3 -dimensional video analysis. Females leave a chemical trail in their wake and a male intercepting a fresh trail initiates a characteristic tracking behaviour in which he increases his speed from $\sim 10$ to $\sim 30 \mathrm{~mm} \mathrm{~s}^{-1}$ and races up the female trail while displaying a tight zigzag motion. Within seconds the male overtakes the female and attempts to catch her. Males faithfully follow even very convoluted trails and successfully track down females after pursuing trails up to $31 \mathrm{~s}$ old and $17 \mathrm{~cm}$ long. The probability of detecting a trail is inversely related to trail age and length. Males often start tracking female trails in the wrong direction before correcting themselves, and the frequency of directional errors increases with increasing trail age. Complicated or disrupted signal trails may cause males to lose the trail. This induces a distinct signal-scanning behaviour characterised by further enhanced swimming speeds of 50 to $70 \mathrm{~mm} \mathrm{~s}^{-1}$, and frequent shifts of direction. The male scans a restricted volume around the point where the trail was lost and often regains the trail and resumes normal tracking behaviour. This behaviour may help males follow trails that are broken by turbulence. A simple generic model of pheromone trails that is consistent with the tracking behaviour of males in C. typicus and other species of copepods was used to explore the characteristics of pheromone trails. Model considerations suggest that these pheromones are small molecules, e.g. amino acids, and that the investment in pheromone production, both in terms of elements and metabolic energy, represents only a small fraction of the females' ingestion and metabolic rate.
\end{abstract}

KEY WORDS: Mating behaviour $\cdot$ Mate detection $\cdot$ Chemical signals $\cdot$ Encounter rates

\section{INTRODUCTION}

Planktonic copepods dominate the zooplankton practically everywhere in the ocean and are among the most abundant animals on earth (Boxshall 1998, Castro \& Huber 2003). Copepods play a key role in the pelagic ecosystem by transferring energy from primary producers to higher trophic levels and constitute the main food source for many larval and juvenile fish species. By grazing on phytoplankton they also become a significant factor in the biogeochemical cycling of organic and inorganic compounds (e.g. Kiørboe 1993, 1997, Lenz 2000). Thus, the factors governing copepod population dynamics are essential to the whole pelagic ecosystem (cf. Howlett 1998).
All animals share 3 main challenges in life: feeding, avoiding predators, and reproducing. While many studies have been done on copepod feeding behaviour and predator-prey interactions, comparatively little is known about copepod mate finding behaviour (Boxshall 1998, Buskey 1998, Lonsdale et al. 1998). Mating is an essential life-history feature, and mate encounter rates may be vital for copepod population dynamics. Copepods cannot see (although light may be perceived) and are therefore dependent on non-visual senses for detecting and identifying food, predators, and mates in their 3-dimensional surroundings. Given the low concentration of adult copepods in most natural populations - in some species a few individuals per cubic metre or less - the challenge of finding a mate seems enormous (cf. Boxshall 1998). 
Earlier studies have suggested the involvement of pheromones in the mate finding of pelagic copepods, both for marine and freshwater species (e.g. Parker 1902, Katona 1973, Griffiths \& Frost 1976, Watras 1983, Uchima \& Murano 1988, van Leeuwen \& Maly 1991, Lazzaretto et al. 1994). More recent investigations based on filming free-swimming individuals have described in detail remote detection of mates by chemical signalling. In several species, cruising females leave a chemical trail in their wake. Tsuda \& Miller (1998) found that females of Calanus marshallae deposit vertical chemical trails, which males may detect and follow downwards to the female. Likewise, Doall et al. (1998), Weissburg et al. (1998), and Yen et al. (1998) described females of Temora longicornis signalling their presence to males by releasing chemicals in their trails. Colin (1995) reported males of Centropages typicus and $C$. hamatus locating females by following their chemical trails. In other species, pheromones are obviously involved in mate detection, but rather in the form of pheromone clouds than distinct pheromone trails, e.g. in Pseudocalanus elongatus (Kiørboe et al. 2005, this volume) and in the freshwater copepod Leptodiaptomus ashlandi (Nihongi et al. 2004). In yet other copepods mate detection may rely on hydromechanical signals, but this has been described for very few species, e.g. Acartia tonsa (Doall et al. 2001, Bagøien \& Kiørboe 2005, this volume) and the freshwater copepod Cyclops scutifer (Strickler 1998). In these species, males detect hydromechanical signals from hops made by closely situated females, and mating is preceded by a series of hops synchronised between the 2 mates.

Obviously, signal extension and detectability may vary among different types of signals and among species, and this may have implications for mate encounter rates and population dynamics. The objective of our project was to add insight into the functioning of the diverse modes of mate-signalling and matefinding behaviour in pelagic copepods in order to estimate mate encounter rates and examine the population dynamical implications of the constraints posed by limitations in mate encounter rates. In this paper we describe the mate-finding behaviour of Centropages typicus and identify the mechanism governing mate detection and location in this species. We visualize how $C$. typicus females deposit pheromone trails that males may find and follow, similar to what has been observed in several species, and we suggest a simple generic model by which we explore the characteristics of pheromone trails. In companion papers we describe and model mate-finding behaviours in other species (Bagøien \& Kiørboe 2005, Kiørboe et al. 2005, and subsequent papers use this insight to estimate mate encounter rates (Kiørboe \& Bagøien 2005) and examine population dynamical implications (Kiørboe unpubl.).

\section{MATERIALS AND METHODS}

Centropages typicus was collected from the North Sea in August 2003. A continuous culture was established at $14^{\circ} \mathrm{C}$ in the dark and reared on a mixed diet of the phytoplankton Rhodomonas baltica, Thalassiosira weissflogii, and Heterocapsa triqueta. Freshly moulted adult males and females were sorted and the sexes separated 2 to $4 \mathrm{~d}$ prior to the mate-finding video experiments.

Then, 20 to 30 preseparated individuals of each sex were brought together in a 11 Plexiglas aquarium $\left(10 \times 10 \times 10 \mathrm{~cm}^{3}\right)$ and video-filmed while swimming freely. Rhodomonas baltica in concentrations of roughly $10^{7}$ cells $\mathrm{l}^{-1}$ was added as food in all experiments, which were conducted at rearing temperature and lasted $4 \mathrm{~h}$. In all experiments, females observed carrying spermatophores were excluded.

Under the conditions described above, the swimming behaviour of males in the absence of females, and vice versa, was filmed. The effect on swimming behaviour of filtrate from the opposite sex was tested; 20 individuals were filmed for $30 \mathrm{~min}$ while incubated in water which had held 4 individuals $\mathrm{l}^{-1}$ of the opposite sex over the preceding $3 \mathrm{~d}$.

The 3D video set-up consisted of 2 orthogonally oriented and synchronised b/w CCD video cameras (Watec, WAT-535EX) equipped with $50 \mathrm{~mm}$ Cosmicon lenses. Each camera was connected to a separate video recorder (Panasonic AG-MD830, Super VHS, 25 frames $\mathrm{s}^{-1}$ ), via a date-time generator (Panasonic WJ $810,1 / 100 \mathrm{~s}$ ), as well as to a monitor. For each camera, illumination was provided from the far side of the aquarium by an infrared-light-emitting diode (LED). No white light was admitted. By collimating the light through condensers $(30 \times 30 \mathrm{~cm})$ the same length calibration applied to all parts of the aquarium. Each camera overlooked the aquarium from the side, and the various components of the set-up were adjusted so that the copepods were adequately resolved and in focus. The copepods were seen as shadows in the recordings. Each video experiment started with a size calibration where a $10 \mathrm{~mm}$ diameter sphere was lowered into the middle of the aquarium and filmed with both cameras.

The 2 cameras represented the XZ- and the YZplanes of the aquarium; 3D swimming patterns of target individuals were obtained by combining information from the $2 \mathrm{D}$ views. A total of 25 selected mate finding sequences recorded by both cameras were digitised and imported into the image analysis software 'Image J'. Here the 3D positions of both target individuals were determined for each time step (1/25 s) by manually marking the middle of the targets on each of the 2 corresponding 2D video frames. Most calculations were based on data obtained from the digitised 
video sequences. However, for some purposes these data were supplemented by video observations and measurements made directly from the monitor. A total of 84 mating-related events, including the 25 digitised cases, were recorded on video. The sex of a given individual in the mate-finding experiments could not be determined from the video records. However, Blades (1977) documented that Centropages typicus males use their geniculate antennules to catch females by grasping their urosomes. Thus, we consequently defined the individuals actively pursuing and catching their mates to be males, and vice versa. All digitised events were animated in MATLAB. The 3D swimming patterns and trajectories of both target individuals in a given mate-finding event could thereby be studied from various angles and at different velocities.

\section{RESULTS}

In a typical mate finding event, a male cruising at $\sim 5$ to $10 \mathrm{~mm} \mathrm{~s}^{-1}$ intercepts a 'fresh' trail from a female swimming in helical loops at $\sim 5 \mathrm{~mm} \mathrm{~s}^{-1}$ (Figs. 1 to 3 ). Upon crossing the trail, the male detects and responds to some signal released by the female. The male now abandons his smooth cruising motion and initiates a distinctive tracking behaviour. The tracking behaviour is characterised by an increased velocity, typically fluctuating around $30 \mathrm{~mm}$ $\mathrm{s}^{-1}$, combined with a tight zigzag movement relative to the net swimming direction. During the tracking phase, the male races after the female, staying close to her trail. The tracking male rapidly closes in on the female, who maintains her swimming speed and pattern. When the male reaches within a few body lengths from the female, he leaps straight towards her and attempts to catch her. The whole pursuit lasts only a few seconds. At times the male reduces his velocity somewhat just prior to the mate catch.

When a female produces a complicated or disrupted signal trail, for instance by performing tight loops or hops, males in pursuit tend to lose track of the trail. This induces a distinct signal-scanning behaviour in the male, which is characterised by a strongly increased swimming velocity typically fluctuating around $50 \mathrm{~mm} \mathrm{~s}^{-1}$ combined with frequent shifts of direction (Figs. 2 \& 3). While displaying this behaviour, the male typically remains within a restricted volume around the point where the track was lost. In many cases the male is able to relocate the trail and may resume normal tracking behaviour, ultimately finding the female.
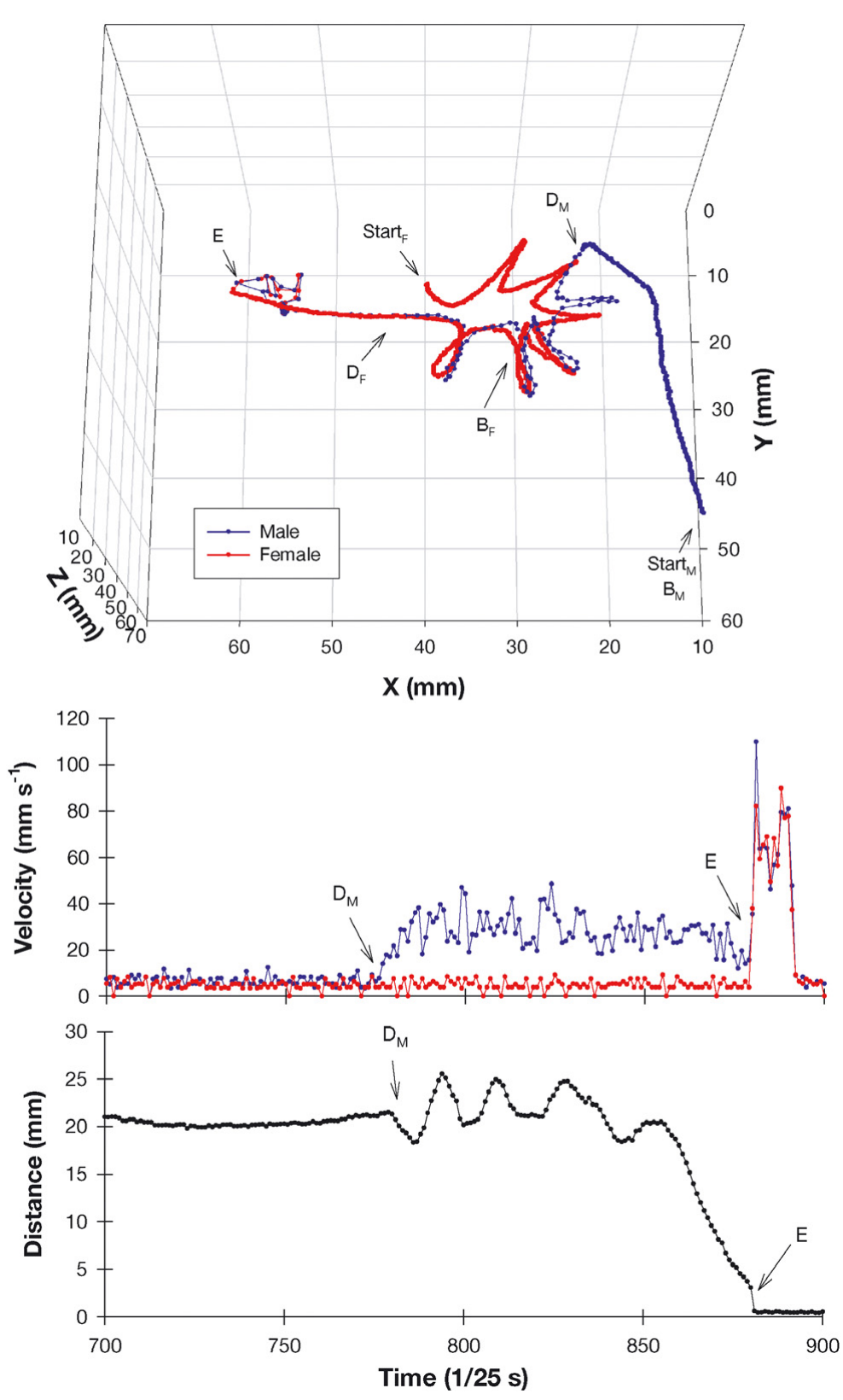

Fig. 1. Centropages typicus. A cruising male intercepts a $22 \mathrm{~s}$ old helical female trail. The male tracks the $14 \mathrm{~cm}$ long trail and catches the female after $4 \mathrm{~s}$. Top: Swimming trajectories of male (blue) and female (red). Subsequent points are temporally separated by $1 / 25 \mathrm{~s}$. The female trajectory begins $24 \mathrm{~s}$ before that of the male. Temporally corresponding male and female positions before signal detection are indicated by ' $\mathrm{B}_{\mathrm{M}}$ ' and ' $\mathrm{B}_{\mathrm{F}}$ ', respectively. Male and female positions at time of signal detection are marked ' $\mathrm{D}_{\mathrm{M}}$ ' and ' $\mathrm{D}_{\mathrm{F}}$ ', while the encounter position is marked ' $\mathrm{E}$ '. Middle: Swimming velocities of male (blue) and female (red) with time. Times of signal detection and encounter are indicated as above. Bottom: Straight distance between male and female with time 
Males often start tracking female trails in the wrong direction before turning back and pursuing the female in the right direction. Initial trail tracking in the wrong direction was observed in 13 of 49 cases $(\sim 27 \%)$, and the proportion of such mistakes was markedly higher when males were intercepting old rather than fresh trails (Fig. 4). In 3 of the 13 cases classified as 'initial tracking in the wrong direction', the male first made a few moves in the right direction, then turned and tracked the wrong way, and finally turned once more and tracked in the right direction.
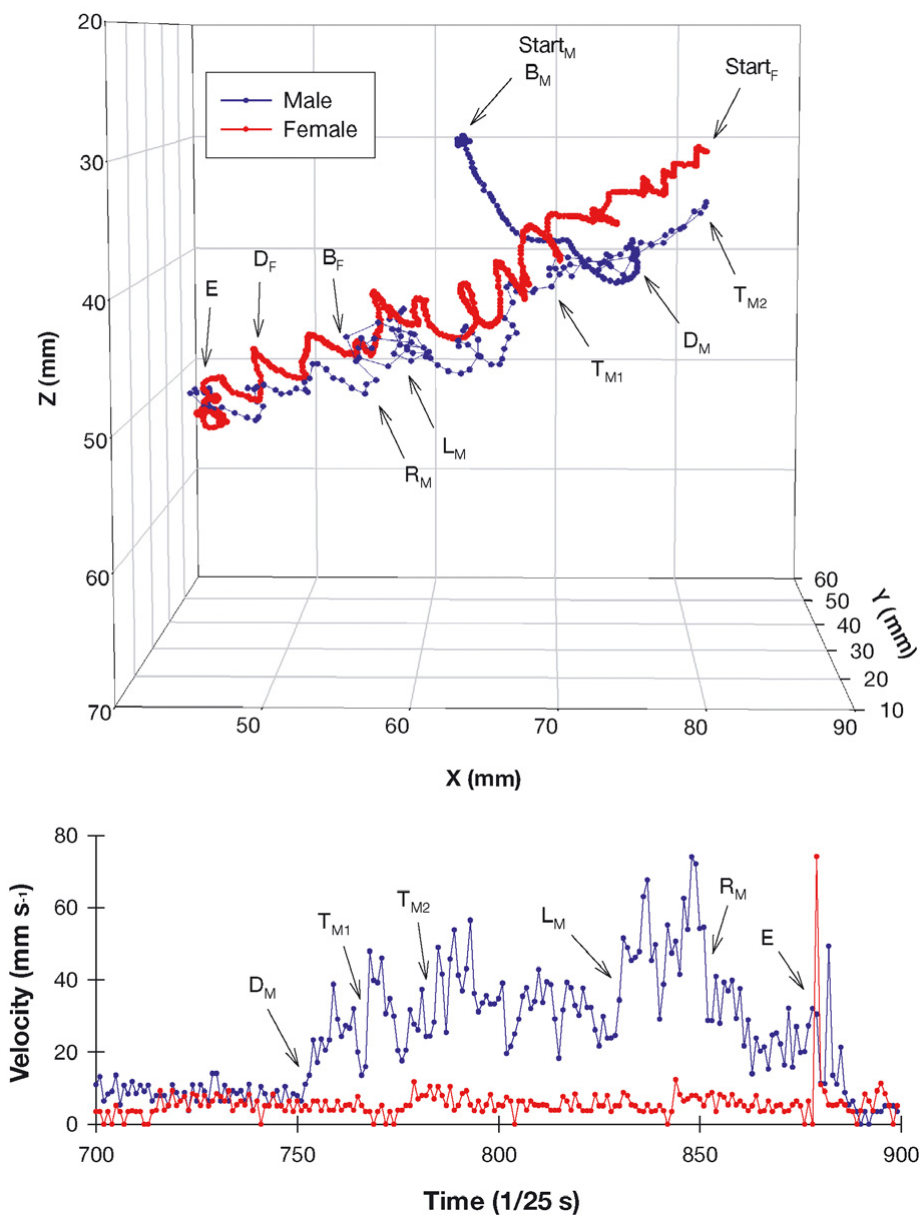

Fig. 2. Centropages typicus. A cruising male intercepts a $23 \mathrm{~s}$ old helical female trail. The male starts tracking the $17 \mathrm{~cm}$ long trail in the right direction for $0.6 \mathrm{~s}$ (to $\mathrm{T}_{\mathrm{M} 1}$ ), then tracks in the wrong direction for $0.6 \mathrm{~s}$ (to $\mathrm{T}_{\mathrm{M} 2}$ ), and finally resumes tracking in the right direction. The female is encountered $3.8 \mathrm{~s}$ later, following a loss $\left(\mathrm{L}_{\mathrm{M}}\right)$ and reencounter $\left(\mathrm{R}_{\mathrm{M}}\right)$ of the trail. Top: Swimming trajectories of male (blue) and female (red). Subsequent points are temporally separated by $1 / 25 \mathrm{~s}$. The female trajectory begins $24 \mathrm{~s}$ before that of the male. Temporally corresponding male and female positions before signal detection are marked ' $\mathrm{B}_{\mathrm{M}}$ ' and ' $\mathrm{B}_{\mathrm{F}}$ ', respectively. Male and female positions at the time of signal detection are marked ' $\mathrm{D}_{\mathrm{M}}$ ' and ' $\mathrm{D}_{\mathrm{F}}{ }^{\prime}$, and the encounter position is marked ' $\mathrm{E}$ '. Bottom: Swimming velocities of male (blue) and female (red) with time

\section{Examples of mate finding}

Case 1 (Fig. 1, Table 1). A male cruising in an almost straight path with an average speed of $6 \mathrm{~mm}$ $\mathrm{s}^{-1}$ intercepts the $22 \mathrm{~s}$ old trail from a female cruising in helical loops with an average speed of $5 \mathrm{~mm} \mathrm{~s}^{-1}$. The male detects the female signal and responds by racing up her $14 \mathrm{~cm}$ long helical trail with an average speed of $28 \mathrm{~mm} \mathrm{~s}^{-1}$ while displaying a tight zigzag swimming motion. After $\sim 4 \mathrm{~s}$ of tracking he has almost reached the female and now slows down slightly. From a distance of $3 \mathrm{~mm}$, the male makes a
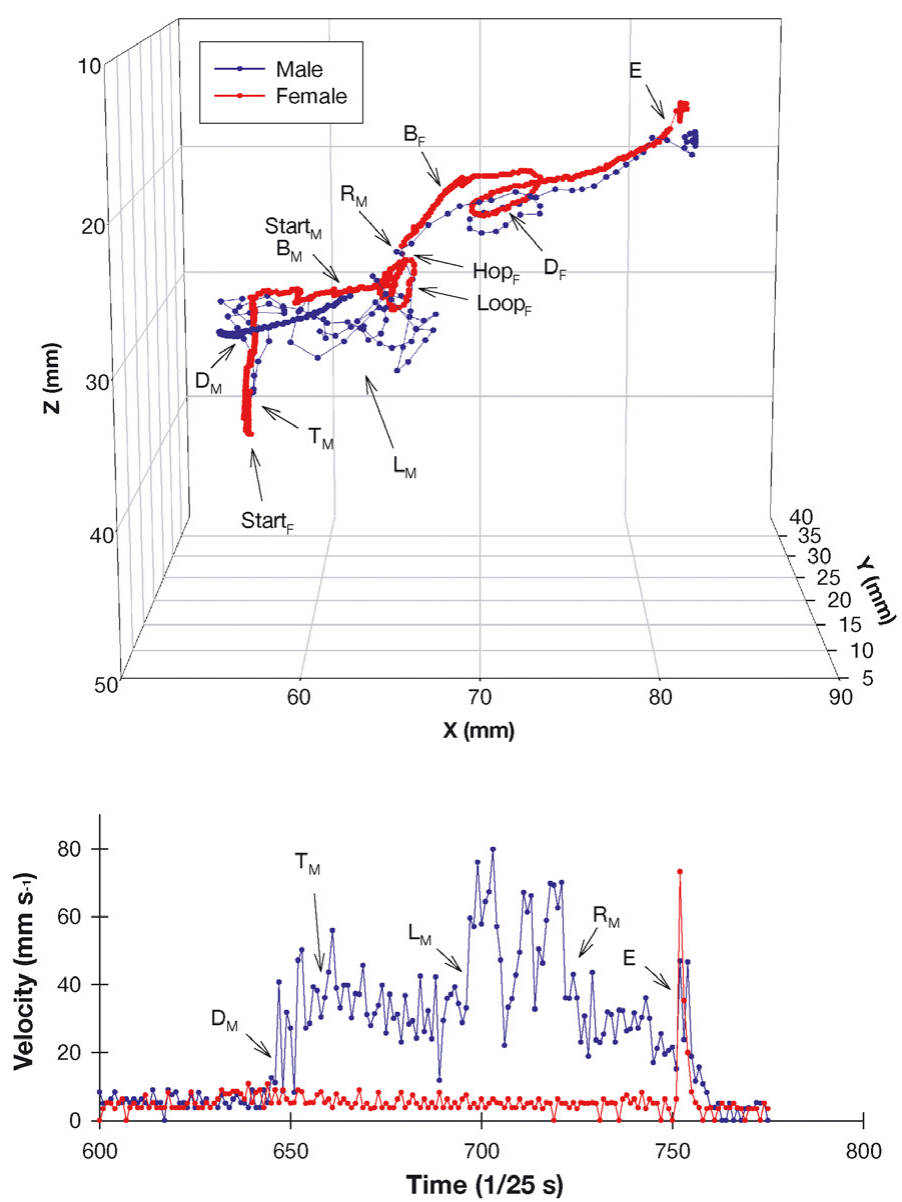

Fig. 3. Centropages typicus. A cruising male intercepts an $11 \mathrm{~s}$ old female trail. The male tracks the $8 \mathrm{~cm}$ long trail in the wrong direction for $0.5 \mathrm{~s}$, then turns back $\left(\mathrm{T}_{\mathrm{M}}\right)$ and tracks in the correct direction. The male encounters the female $3.7 \mathrm{~s}$ later, after losing $\left(\mathrm{L}_{\mathrm{M}}\right)$ and regaining $\left(R_{M}\right)$ the trail at a point where the female performed a tight loop $\left(\right.$ Loop $\left._{\mathrm{F}}\right)$ followed by a hop $\left(\mathrm{Hop}_{\mathrm{F}}\right)$. Top: Swimming trajectories of male (blue) and female (red). Subsequent points are temporally separated by $1 / 25 \mathrm{~s}$. The female trajectory begins $15 \mathrm{~s}$ before that of the male. Corresponding male and female positions before signal detection are indicated by ' $\mathrm{B}_{\mathrm{M}}$ ' and ' $\mathrm{B}_{\mathrm{F}}$ ', respectively. Male and female positions at the time of signal detection are marked ' $D_{M}$ ' and ' $D_{F}$ '. The encounter position is marked ' $E$ '. Bottom: Swimming velocities of male (blue) and female (red) with time 
leap and successfully catches the female. The attached couple performs a cyclic swimming motion with a great velocity for about $1 \mathrm{~s}$. Thereafter the swimming activity almost ceases, with the couple remaining attached.

Case 2 (Fig. 2, Table 1). A directionally persistent male cruising with an average speed of $9 \mathrm{~mm} \mathrm{~s}^{-1}$ intercepts the $23 \mathrm{~s}$ old trail of a female performing helical loops at an average speed of $5 \mathrm{~mm} \mathrm{~s}^{-1}$. The male detects the female signal and responds by tracking the $17 \mathrm{~cm}$ long trail with an average speed of $30 \mathrm{~mm} \mathrm{~s}^{-1}$. Initially he tracks the trail in the right direction for $\sim 0.6 \mathrm{~s}$, after which he turns around and tracks in the opposite and wrong direction for $\sim 0.6 \mathrm{~s}$. Then he corrects himself by turning back once more and resumes tracking in the right direction. When the male has covered about half of the trail distance to the female, he seems to lose the trail. This is indicated by the male performing a signal-scanning behaviour for about $1 \mathrm{~s}$, where he increases his average speed to $52 \mathrm{~mm} \mathrm{~s}^{-1}$ while frequently shifting direction, all the while remaining within a restricted volume close to the trail. The male then regains the trail and resumes the typical tracking behaviour. The female is encountered, although not caught, $3.8 \mathrm{~s}$ after the male made his final change of tracking direction prior to the signal scanning phase. A video clip and 3D animation of this mating event is available as an Electronic Supplement (www.int-res.com/ articles/suppl/blind-dating/).

Case 3. (Fig. 3, Table 1). A male cruising at an average speed of $6 \mathrm{~mm} \mathrm{~s}^{-1}$ detects the $11 \mathrm{~s}$ old trail of a female cruising along a somewhat irregular path at an average speed of $5 \mathrm{~mm} \mathrm{~s}^{-1}$. About midway in the $8 \mathrm{~cm}$ long trail the female makes a loop and thereafter a hop before she continues cruising in a straighter manner. The male starts tracking the trail with an average velocity of $31 \mathrm{~mm} \mathrm{~s}^{-1}$, but in the wrong direction. After $\sim 0.5 \mathrm{~s}$ he turns and continues tracking in the right direction. When the tracking male reaches the point of the female loop and hop, he appears to lose the trail. This is indicated by the male exhibiting a signal-scanning behaviour which lasts for $\sim 1.5 \mathrm{~s}$, displaying the increased average velocity of $56 \mathrm{~mm} \mathrm{~s}^{-1}$ combined with frequent shifts of direction. The scan is made in a volume close to the point of the female loop and hop, and the male also swims back and forth along the female trail just prior to this point. The male then regains the trail and continues his pursuit of the female performing normal tracking behaviour and staying close to the female path. The male encounters the female $3.7 \mathrm{~s}$ after changing tracking direction in the early part of the pursuit phase, and the female escapes by jumping away.

\section{Summary}

Males tracked down and caught females after encountering trails up to $31 \mathrm{~s}$ old (Table 1). The longest lasting successful tracking event observed was $\sim 6 \mathrm{~s}$ and included loss and regain of the trail. Males successfully pursued female trails up to $17 \mathrm{~cm}$ long, while the largest 3D straight-line distance between male and female at time of detection was $3 \mathrm{~cm}$ (Table 1). Males tracked female trails in the wrong direction for up to $2 \mathrm{~cm}$ and $0.6 \mathrm{~s}$ before correcting themselves. In 14 of the 25 digitised tracking events the male caught the female, while in the remaining 11 cases the chase ended with a mere encounter due to the female escaping or the male appearing to lose interest in the female (Table 1). In some cases tracking males seemed to lose the trail and did not succeed in finding the female.

Males displayed no tracking or signal-scanning behaviour when filmed in the absence of females.
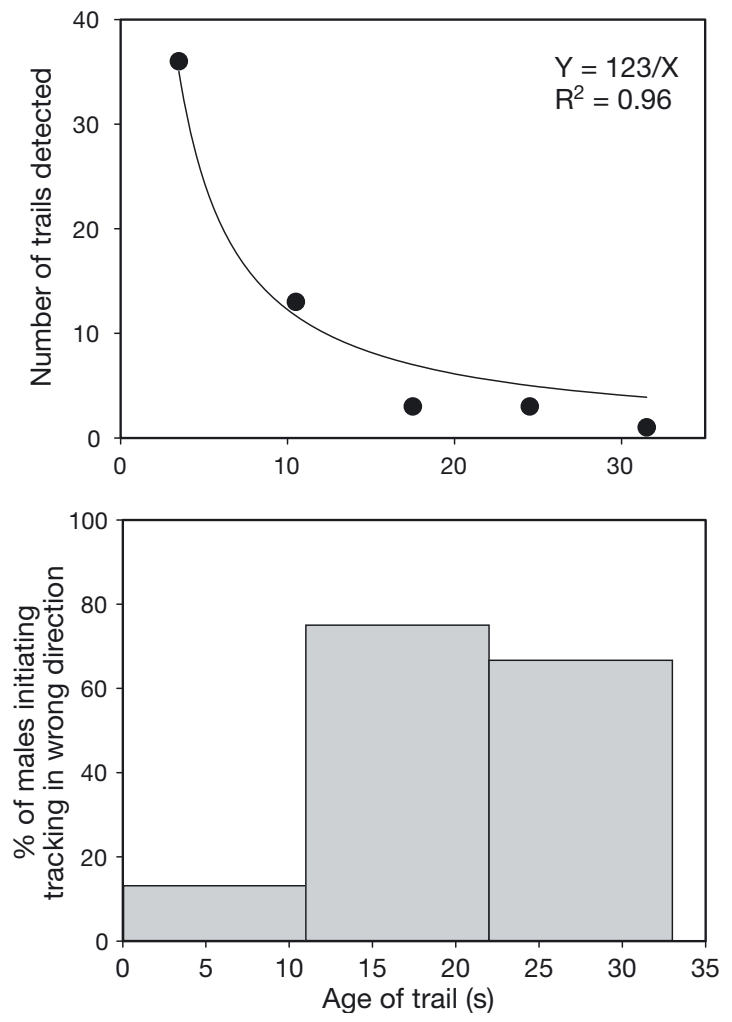

Fig. 4. Centropages typicus. Age distribution of female trails at time of signal detection by the male and the percentage of events where tracking was initiated in the wrong direction. Upper: Age distribution of female trails at time of signal detection. Frequencies of trail age were estimated from 25 digitised tracks and 31 direct monitor measurements. A hyperbolic model is fitted; $y=a / x$, where ' $y$ ' is the predicted frequency of trail-detection, ' $x$ ' is trail age, and ' $a$ ' is a coefficient. Lower: Percentage of events where tracking was initiated in the wrong direction. Based on 49 monitor observations 
This behaviour was also absent when males were incubated in fresh filtrate from containers holding 4 females $\mathrm{l}^{-1}$. No behaviour similar to tracking or signal scanning was observed for females.

The male trajectory was typically somewhat displaced relative to that of the female, even where the 2 trajectories clearly concurred. This phenomenon is depicted in Figs. 2 \& 3. The minimum 3D straight-line distance between the female trajectory and the point where the male detected the female signal ranged between 0.15 and $8.18 \mathrm{~mm}$ in the 25 digitised cases. The median distance was $1.36 \mathrm{~mm}$, and the mean $\pm \mathrm{SE}$ was $2.05 \pm 1.87 \mathrm{~mm}$.

Trail-detection frequency declined hyperbolically with trail age (Fig. 4) and trail length (not shown). The median trail age at time of detection was $3.8 \mathrm{~s}$, and the average was $6.8 \pm 7.0 \mathrm{~s}$. Thus, males detected fresh trails more readily than old trails.

\section{DISCUSSION}

\section{Male-attracting signal is chemical in nature}

We conclude that Centropages typicus females signal their presence and location to males by releasing a substance chemical in nature. The involvement of chemical signals in mate finding of pelagic copepods has been reported for a number of species (Table 2). Our conclusion

Table 1. Data on 25 digitised mate-finding events including trail tracking

\begin{tabular}{|lcccrrr|}
\hline Outcome & $\begin{array}{c}\text { Trail } \\
\text { age } \\
\text { (s) }\end{array}$ & $\begin{array}{c}\text { Initial } \\
\text { track } \\
\text { direction }\end{array}$ & $\begin{array}{c}\text { Detection } \\
\text { distance } \\
(\mathrm{mm})\end{array}$ & $\begin{array}{r}\text { Trail } \\
\text { length } \\
(\mathrm{mm})\end{array}$ & $\begin{array}{r}\text { Pursuit } \\
\text { length } \\
(\mathrm{mm})\end{array}$ & $\begin{array}{c}\text { Pursuit } \\
\text { duration } \\
(\mathrm{s})\end{array}$ \\
\hline Catch & 1.2 & Correct & 8.5 & 12.6 & 6.1 & 0.1 \\
Catch & 1.4 & Correct & 8.5 & 20.6 & 20.7 & 0.7 \\
Catch & 1.5 & Correct & 12.9 & 22.4 & 17.0 & 0.4 \\
Catch & 1.6 & Correct & 6.8 & 11.0 & 24.1 & 1.0 \\
Encounter & 1.7 & Correct & 4.3 & 33.9 & 49.1 & 1.5 \\
Catch & 2.2 & Correct & 4.5 & 28.2 & 10.7 & 0.4 \\
Catch & 2.3 & Wrong & 3.5 & 26.9 & 75.9 & 2.2 \\
Catch & 2.9 & Correct & 11.1 & 19.6 & 21.3 & 0.8 \\
Catch & 3.2 & Correct & 14.6 & 22.1 & 18.7 & 0.6 \\
Catch & 5.7 & Correct & 5.7 & 50.4 & 28.4 & 1.2 \\
Encounter & 6.2 & - & 10.5 & 79.0 & 170.5 & 5.7 \\
Catch & 8.9 & Correct & 17.0 & 37.3 & 34.6 & 1.1 \\
Catch & 9.6 & Correct & 5.7 & - & 14.2 & 0.5 \\
Encounter & 9.9 & Correct & 19.8 & 64.5 & 33.9 & 1.1 \\
Encounter & 11.0 & Wrong & 21.0 & 68.8 & 52.1 & 1.6 \\
Encounter (Fig. 3) & 11.4 & Wrong & 19.4 & 78.7 & 158.0 & 4.2 \\
Encounter & 11.8 & Correct & 21.4 & 51.8 & 39.5 & 1.7 \\
Encounter & 12.1 & Wrong & 18.4 & 46.7 & 60.9 & 1.8 \\
Encounter & 13.2 & Wrong & 25.3 & 53.9 & 69.6 & 2.0 \\
Catch & 17.8 & Wrong & 12.3 & 138.6 & 198.5 & 6.0 \\
Encounter & 19.2 & - & 15.4 & 82.5 & 179.2 & 4.9 \\
Encounter & 21.3 & Correct & 14.7 & 59.4 & 46.3 & 1.6 \\
Catch (Fig. 1) & 22.0 & Correct & 21.4 & 138.4 & 115.8 & 4.1 \\
Encounter (Fig. 2) & 23.0 & Wrong & 29.9 & 165.6 & 173.1 & 5.0 \\
Catch & 30.8 & Wrong & 25.8 & 60.5 & 61.0 & 1.9 \\
\hline
\end{tabular}

that the signal is a chemical substance, which we interpret as a pheromone, is based on the concurring male and female trajectories prior to mate encounter. Males closely followed female trails, in many cases with complicated spatial structures (Figs. 1 to 3). Only when the male had reached within a few body lengths from the female would he swim directly towards her, presumably just then detecting her hydromechanical signals (cf. Yen et al. 1998). Furthermore, the tracking behaviour of the male demonstrates that the signal trail of the female must be spatially well defined and with sharp gradients perpendicular to its longitudinal axis. Our conclusion of C. typicus males locating females from their chemical trails is in agreement with the results of Colin (1995).

\section{Signal types and distributions, and classification of strategies}

The mate-finding behaviour of Centropages typicus has many similarities with those reported for Calanus marshallae (Tsuda \& Miller 1998) and Temora longicornis (Doall et al. 1998). In all 3 species, males are able to detect and track down females by following their well-defined pheromone trails. The most conspicuous difference regarding the mate-finding behaviour of these species seems to be the form of the pheromone trails, which is determined by the swimming pattern of the female. While C. typicus females typically cruise in near helical loops, females of $T$. longicornis appear to cruise along straighter lines (cf. Doall et al. 1998). During normal swimming, $T$. longicornis males swim along more curved paths than females, in contrast to the behaviour observed in C. typicus. Females of Calanus marshallae, on the other hand, deposit more or less vertical pheromone trails during sinking (Tsuda \& Miller 1998). Females are then located below the point where the trail is encountered, and males would therefore not risk tracking in the wrong direction as is frequently observed for C. typicus and T. longicornis.

The tracking behaviours of Centropages typicus and Temora longicornis, and the chase swimming of Calanus marshallae, seem to be related strategies which are employed to follow well-defined pheromone trails. All include rotation around the longitudinal body axis during forward motion. As suggested by Doall et al. (1998) and Tsuda \& Miller (1998), the purpose of 
Table 2. Mate-finding studies in planktonic copepods including the precontact phase. Signal types for mate detection: $\mathrm{C}$, chemical remote; $\mathrm{H}$, hydromechanical remote; $\mathrm{R}$, random encounter. Classification of mate-finding strategy 3 groups): CT, chemical trail-tracking; $\mathrm{CD}$, chemical diffuse plumes; $\mathrm{H}$, hydromechanical. -: 'not clear'

\begin{tabular}{|c|c|c|c|}
\hline Species & Signal type & Classification & Source \\
\hline Acarti hudsonica & $\mathrm{H}$ & $\mathrm{H}$ & Colin (1995) \\
\hline Acartia tonsa & $\mathrm{H}$ & $\mathrm{H}$ & Bagøien \& Kiørboe (2005) \\
\hline Acartia tonsa & $\mathrm{H}$ & $\mathrm{H}$ & Doall et al. (2001) \\
\hline Calanus marshallae & $\mathrm{C}$ & $\mathrm{CT}$ & Tsuda \& Miller (1998) \\
\hline Calanus pacificus & $\mathrm{C}$ & - & Griffiths \& Frost (1976) \\
\hline Centropages typicus & $\mathrm{C}$ & CT & Present study \\
\hline Centropages typicus & $\mathrm{C}$ & $\mathrm{CT}$ & Colin (1995) \\
\hline Centropages hamatus & $\mathrm{C}$ & $\mathrm{CT}$ & Colin (1995) \\
\hline Cyclops fimbriatus & $\mathrm{R}^{\mathrm{a}}$ & - & Holmes (1903) \\
\hline Cyclops scutifer & $\mathrm{H}$ & $\mathrm{H}$ & Strickler (1998) \\
\hline Diaptomus leptopus & $\mathrm{C}$ & - & van Leeuwen \& Maly (1991) \\
\hline Diaptomus leptopus & $\mathrm{C}^{\mathrm{b}}$ & - & Watras (1983) \\
\hline Eurytemora affinis & $\mathrm{C}$ & - & Katona (1973) \\
\hline Eurytemora herdmani & $\mathrm{C}$ & - & Katona (1973) \\
\hline Eudiaptomus gracilis & $\mathrm{C}^{\mathrm{c}}$ & - & Wolf (1905) \\
\hline Labidocera aestiva & $\mathrm{C}$ & - & Parker (1902) \\
\hline Leptodiaptomus ashlandi & $\mathrm{C}$ & $C D$ & Nihongi et al. (2004) \\
\hline Limnocalanus macrurus & $\mathrm{C}^{\mathrm{b}}$ & - & Roff (1972) \\
\hline Pseudocalanus elongatus & $\mathrm{C}$ & $\mathrm{CD}$ & Kiørboe et al. (2005) \\
\hline Pseudocalanus sp. & $\mathrm{C}$ & - & Griffiths \& Frost (1976) \\
\hline Pseudodiaptomus acutus & $\mathrm{C}$ & - & Jacoby \& Youngbluth (1983) \\
\hline Pseudodiaptomus cokeri & $\mathrm{C}$ & - & Jacoby \& Youngbluth (1983) \\
\hline Pseudodiaptomus coronatus & $\mathrm{C}$ & - & Jacoby \& Youngbluth (1983) \\
\hline Pseudodiaptomus coronatus & $\mathrm{C}$ & - & Katona (1973) \\
\hline Pseudodiaptomus coronatus & - & - & Jacobs (1961) \\
\hline Oithona davisae & $\mathrm{C}$ & - & Uchima \& Murano (1988) \\
\hline Oithona davisae & $\mathrm{C}$ & - & Uchima \& Hirano (1988) \\
\hline Temora longicornis & $\mathrm{C}$ & $\mathrm{CT}(+\mathrm{CD})^{\mathrm{d}}$ & $\begin{array}{l}\text { Doall at al. (1998), Yen et al. } \\
\text { (1998), Weissburg et al. (1998) }\end{array}$ \\
\hline Tigriopus fulvus & $\mathrm{C}$ & - & Lazzaretto et al. (1994) \\
\hline Tigriopus fulvus & $\mathrm{C}$ & - & Lazzaretto et al. (1990) \\
\hline Tortanus sp. & $\mathrm{H}$ & $\mathrm{H}$ & Colin (1995) \\
\hline \multicolumn{4}{|c|}{$\begin{array}{l}{ }^{a} \text { Interpreted as random encounter but could possibly be hydromechanical detection } \\
\text { b Interpreted as chemical detection, although not entirely evident from the paper } \\
{ }^{c} \text { Interpreted as chemical detection from reference by Roff (1972), although not entirely } \\
\text { evident from citation } \\
\text { d Depending on female motion; chemical trail when cruising female and diffusive plume } \\
\text { when hovering female }\end{array}$} \\
\hline
\end{tabular}

haviours seem to be strategies for assessing pheromone signals and gradients where the structure of the trail is unclear, for the purpose of relocating structured trails. Tracking males of C. typicus (present study) and $T$. longicornis (Doall et al. 1998, Weissburg et al. 1998) are able to relocate trail structures and continue pursuing the female after temporarily losing the trail, for instance due to complicated swimming patterns or hovering of the female as well as due to female hops. Turbulence may stretch, twist, and 'break' chemical trails (Visser \& Jackson 2004) and might also degrade the trails into more diffuse signal distributions. We suggest that the signal-scanning behaviour of C. typicus, and the related behaviour observed for other species, enables copepods to pursue pheromone trails that have been distorted and broken by turbulence.

Centropages typicus males increase their swimming velocities during tracking and even more so when performing signal-scanning behaviour. The male needs to increase his swimming velocity during tracking in order to overtake the cruising female. As discussed by Yen et

the rotation could be to sample and assess the signal gradient perpendicular to the trail direction, hence continuously providing the tracking male with information about where the centre of the trail is located (but see also Dusenbery 1992). The signal-scanning behaviour observed in C. typicus resembles the 'casting behaviour' described for $T$. longicornis (Doall et al. 1998, Weissburg et al. 1998) and the 'dancing behaviour' described for C. marshallae (Tsuda \& Miller 1998). All these behaviours are characterised by complex swimming patterns with sharp turns and loops within a restricted volume. In all 3 species, this behaviour may precede tracking or chase behaviour and is also typical at complicated parts of the trails, for instance where females have hopped (observed for $T$. longicornis and C. typicus). As concluded by Doall et al. (1998), Weissburg et al. (1998), and Tsuda \& Miller (1998), the signal-scanning, casting, and dancing be- al. (1998), increased velocities also imply a reduced thickness of the boundary layer around the male sensory cells, which implies reduced diffusion times for the signal molecules and hence a reduced reaction time for the male. Likewise, increasing the turnover rate of the water surrounding the sensory cells would provide the copepod with 'fresher' information regarding its immediate surroundings, which should aid the chemical guiding (cf. Dusenbery 1992). Why the velocity is increased even more during signal-scanning behaviour is not clear, but one might speculate that in addition to the reasons suggested above, the increased velocity might help limit the age of the trail before it is relocated, hence increasing the probability of ultimately locating the female.

A few examples of detection and pursuit of mates mediated by chemical signals distributed in diffuse plumes or 'clouds', rather than well-defined trails, 
have been reported and appear to apply to species or situations in which the female is hovering rather than cruising (Doall et al. 1998, Nihongi et al. 2004, Kiørboe et al. 2005). In other species remote mate detection appears to be based on hydrodynamic signalling (Strickler 1998, Bagøien \& Kiørboe 2005). Following the ideas of Doall et al. (1998), Weissburg et al. (1998), and Yen et al. (1998), we suggest dividing mate finding in pelagic copepods into 3 main categories, depending both on the type of mechanism used for mate signalling and the swimming behaviour of the signaltransmitting individual: (1) chemical detection and tracking of mates in well-defined signal trails, (2) chemical detection and pursuit of mates in diffuse signal plumes, and (3) hydromechanical detection and pursuit of mates. All species for which sufficient information is available appear to fall into primarily one of these 3 categories (Table 2).

\section{Displacement of the male trajectory}

The male trajectory was displaced by ca. $2 \mathrm{~mm}$ relative to that of the female. Often, but not always, the male trajectory would be located below the female trajectory. The same phenomenon was reported from the mate finding studies on Temora longicornis by Yen et al. (1998) and Doall et al. (1998), where the displacements ranged between 0.25 and $3.33 \mathrm{~mm}$. These authors suggested that the chemical trail is displaced by the feeding current, since the female has a tilted body angle relative to the net swimming direction, and that the posteriorly directed feeding current may force the female pheromones down below her urosome. We assume that this applies to Centropages typicus as well, but we do not dismiss the possibility that potential advection in the aquarium has an additional effect. In any case, molecular diffusion evidently fails to explain the displacement, as also concluded by Yen et al. (1998). Below, we present a model for the pheromone trail of $C$. typicus which includes the effect of molecular diffusion. This model predicts the maximum radius of a $17 \mathrm{~cm}$ long trail to be only $\sim 0.2 \mathrm{~mm}$, and molecular diffusion is thus negligible in this context.

\section{Characteristics of pheromone trails}

To explore the characteristics of pheromone trails we suggest a simple generic model that applies equally well to all 'trail trackers'. The simplest way to model pheromone trails is to describe the swimming female as a moving point source of velocity $U$ that releases pheromones of diffusivity $D$ at a constant rate $Q$. This model has been used to describe similar phenomena (e.g. Okubo 1980, Jackson \& Kiørboe 2004), and analytical solutions to the advection-diffusion equation are available in the literature (Csanady 1973). The steadystate concentration field $C_{z, r}$ is given by

$$
C_{z, r}=\frac{Q}{4 \pi D z} \exp \left(-\frac{U r^{2}}{4 D z}\right)
$$

where $z$ is the along-track distance behind the copepod and $r$ the radial distance from the track centreline. Right at the centreline $(r=0)$, the exponential term becomes 1 , and hence

$$
C_{z}=\frac{Q}{4 \pi D z}
$$

and the concentration distribution in the centre of the track thus becomes identical to that of a non-moving point source (e.g. Berg 1993). Counterintuitive but true.

Several features of the model are consistent with observation. (1) The model yields a long, slender, and well-defined pheromone trail behind the female just as the tracking behaviour of the male would suggest (Fig. 5). (2) The observed encounter frequency between male Centropages typicus and female trails varies inversely with trail age (Fig. 4) and hence with along-track distance to the female, which is consistent with the hyperbolic along-track decline in pheromone concentration predicted by Eq. (2); a similar pattern is observed in the data for Temora longicornis reported by Doall et al. (1998, their Table 1). (3) The observed abrupt increase in the fraction of directionally confused males with increasing trail age and along-trail distance to the female (Fig. 4) is consistent with the predicted variation in the steepness of the along-trail concentration gradient, $d C / d z$, which varies inversely with the along-track distance squared, i.e. declines rapidly. Thus, the model appears to describe essential features of the pheromone trail properly, and we can therefore use it to explore the characteristics of this means of mate communication.

\section{Trail dimensions}

If we assume that there is a critical threshold for detection, $C^{*}$, then we can estimate the length, $L$, of the detectable trail by inserting $C=C^{*}$ and $z=L$ in Eq. (2), hence

$$
L=\frac{Q}{4 \pi D C^{*}}
$$

Note that the trail length, somewhat counterintuitively, is independent of the swimming velocity of the female, i.e. whether the female is swimming fast or slow, the length of the detectable trail she leaves 


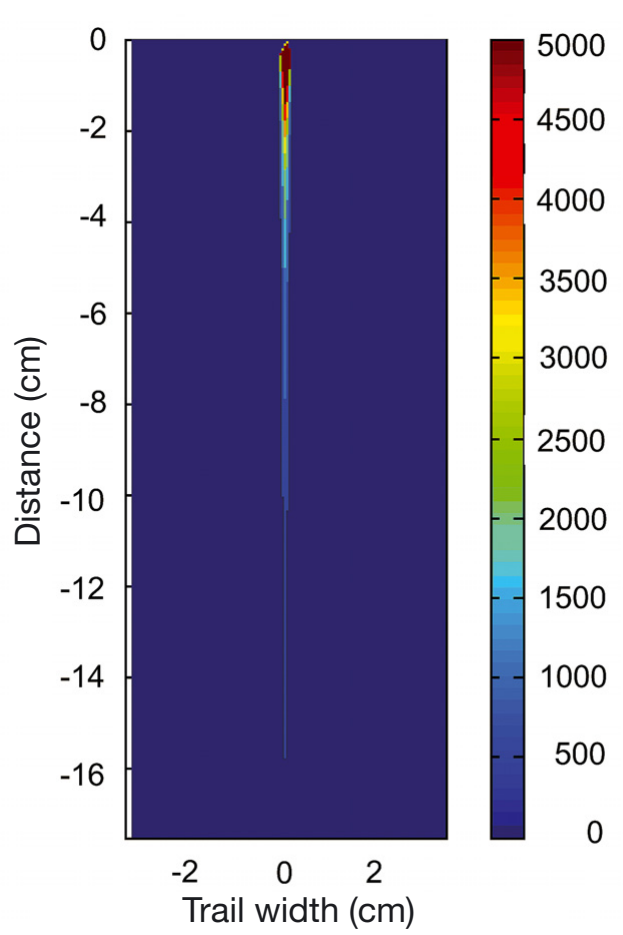

Fig. 5. Centropages typicus. Pheromone trail produced by a female cruising at $0.5 \mathrm{~cm} \mathrm{~s}^{-1}$ as predicted by Eq. (1). A pheromone diffusivity of $D=10^{-5} \mathrm{~cm}^{2} \mathrm{~s}^{-1}$ is assumed. Contour levels are values of $C / Q$ in units of $\mathrm{s} \mathrm{cm}^{-3}$

remains the same. However, as shown below, a slow swimmer leaves a broader trail than a fast swimmer. As a first approximation, it is fair to assume that the sensitivity to chemical signals, $C^{*}$, is independent of copepod size. Eq. (3) then implies that trail length is directly proportional to the pheromone production rate $(Q)$, which in turn is likely to increase with copepod size. We would thus expect larger copepods to produce longer detectable trails than smaller copepods, which is consistent with the few observations available: $6.5 \mathrm{~cm}$ long trails in $1.0 \mathrm{~mm}$ sized (cephalothorax length) Temora longicornis (Doall et al. 1998), $17 \mathrm{~cm}$ in $1.3 \mathrm{~mm}$ Centropages typicus, and $50 \mathrm{~cm}$ in $3.0 \mathrm{~mm}$ Calanus marshallae (Tsuda \& Miller 1998).

The maximum width $(\rho)$ of the plume perpendicular to its length axis and its cross-sectional area $(\sigma)$ 'along' the trail are relevant for estimating mate encounter rates (Kiørboe \& Bagøien 2005) and can be computed (Jackson \& Kiørboe 2004) as

$$
\begin{aligned}
& \rho=2 \sqrt{\frac{Q}{\mathrm{e} \pi C^{*} U}} \\
& \sigma=\frac{0.24}{D U^{0.5}}\left(\frac{Q}{\pi C^{*}}\right)^{1.5}
\end{aligned}
$$

where e is the base of the natural logarithm. Combined with Eq. (3) this yields

$$
\begin{aligned}
& \rho=2 \sqrt{\frac{4 D L}{\mathrm{e} U}} \\
& \sigma \cong 2 L \sqrt{\frac{D L}{U}}
\end{aligned}
$$

Plume width and transsectional area are then cast in terms of parameters that can be measured experimentally $(L, U)$ or assumed with good accuracy $(D=$ $10^{-5} \mathrm{~cm}^{2} \mathrm{~s}^{-1}$, see below). The faster the female, the narrower the trail and the smaller the cross-sectional area. For example, the maximum width of the $17 \mathrm{~cm}$ long trail generated by Centropages typicus, using typical values $\left(U=0.5 \mathrm{~cm} \mathrm{~s}^{-1}, D=10^{-5} \mathrm{~cm}^{2} \mathrm{~s}^{-1}\right)$, is $0.4 \mathrm{~mm}$, indeed a long, slender trail.

\section{Identity of pheromones and cost of trail generation}

How expensive is it to produce diffusive pheromones? This question is difficult to address in an exact way because we know little about the nature of the signal molecules. In contrast, for some harpactacoid copepods (e.g. Tigriopus japonica), postcontact mate recognition has been shown to be mediated by contact pheromones, which have been identified as large surface glycoprotein molecules (e.g. Snell \& Carmona 1994, Frey et al. 1998, Kelly \& Snell 1998, Kelly et al. 1998, Ting et al. 2000, Ting \& Snell 2003). Diffusing pheromones are likely to have different characteristics than the large contact pheromones, and a first guess would be that the signal molecules should be small, amino acids for example, since copepods show both neurophysiological (Yen et al. 1998) and behavioural (Poulet \& Quellet 1982, Gill \& Poulet 1988) responses to elevated concentrations of amino acids, as do many other crustaceans (e.g. Thomson \& Ache 1980), and amino acids are even known to elicit trail-tracking behaviour in some copepods (Kiørboe 2001). Also, amino acids have been identified as signal molecules in other invertebrates (e.g. Riffell et al. 2002). Small peptides, due to their higher degree of potential specificity and slower degradation rate (Decho et al. 1998), would be another candidate group of signal molecules. Theoretical considerations support the idea that signal molecules should be small. From Eq. (3), $L \sim Q / D$, one would argue that, for a given pheromone production rate $(Q)$, the longest trail is obtained using molecules with low diffusivity, i.e. large molecules of high molecular weight $(m)$. However, there is a trade-off here, since the material investment increases proportionally with $m$, whereas the diffusivity of molecules scales with approximately $m^{-1 / 3}$. Thus, for a given investment, the longest trail is obtained using small molecules. The diffusivity of all small biological molecules is on the order of $10^{-5} \mathrm{~cm}^{2} \mathrm{~s}^{-1}$, which we consequently use in our considerations. 
Let us therefore assume that trail pheromones in pelagic copepods are amino acids. Threshold concentrations for copepod behavioural responses to amino acids are on the order of $10^{-8} \mathrm{M}$ (Kiørboe \& Thygesen 2001 and references therein), hence for Centropages typicus from Eq. (3), $Q=4 \pi D C^{*} L \simeq 2 \times 10^{-9} \mathrm{~mol}$ amino acid $\mathrm{d}^{-1}$. The saturated ingestion rate of $C$. typicus would be on the order of $>10^{-7} \mathrm{~mol} \mathrm{~N} \mathrm{~d}^{-1}$ (estimated from Fryd et al. 1991). Thus, the investment in pheromone production represents only a relatively small fraction of the ingested material, even if pheromones are produced continuously and even if the pheromones are dipeptides rather than amino acids.

There is also a biochemical cost of pheromone production. For amino acids, the main cost is due to active transport across the gut wall, which can be estimated as $1 \mathrm{~mol}$ of ATP per mol of amino acid (Kiørboe et al. 1985). For dipeptides, there is an additional biosynthetic cost of peptide formation, approx. 3 mol ATP per mol peptide bond, thus a total metabolic cost of $5 \mathrm{~mol}$ ATP per mol dipeptide (Kiørboe et al. 1985). Since approx. $4.25 \mathrm{l} \mathrm{O}_{2}$ is respired for each mol of ATP produced, the biochemical costs of pheromone production corresponds to respiration rates of $2 \times 10^{-9} \times 4.25=$ $8.5 \times 10^{-9} \mathrm{l} \mathrm{O}_{2} \mathrm{~d}^{-1}$ and $4.25 \times 10^{-8} \mathrm{l} \mathrm{O}_{2} \mathrm{~d}^{-1}$ if the signal molecule is an amino acid or a dipeptide, respectively. Metabolic rates in small copepods of the size of Centropages typicus are on the order of 2 to $5 \times 10^{-6} 1 \mathrm{O}_{2} \mathrm{~d}^{-1}$ (Kiørboe et al. 1985, Ikeda et al. 2001), again suggesting that the cost of pheromone production is low.

In conclusion, females of Centropages typicus and several other pelagic copepods produce long pheromone trails in their wake, with the larger copepods producing the longest trails. The pheromone signals the presence and position of the female since the trails can be found and followed by males. The behavioural repertoire of the male includes a strategy for relocating spatially complex trails, which can be broken or distorted. This may compensate for the detrimental effect of turbulence on signalling efficiency. Pheromone production and signalling appears to represent only a relatively small investment, but it may be very rewarding in terms of mate encounter rates, which can be elevated by orders of magnitude.

Acknowledgements. E.B. was financed through a European Community Marie Curie postdoctoral fellowship (MCFI-200201148) under the programme Improving the Human Potential. T.K. received financial support from the Danish Natural Science Research Council (21-01-0549). We are indebted to $\mathrm{H}$. Parner for assistance with computer and software issues and to U. Thygesen for writing the MATLAB script allowing animation of mate finding events. A. W. Visser is acknowledged for valuable discussions on biological-physical interactions, and J. Melbye is thanked for laboratory assistance. Four anonymous reviewers provided constructive comments and helped improve the manuscript.

\section{LITERATURE CITED}

Bagøien E, Kiørboe T (2005) Blind dating-mate finding in planktonic copepods. III. Hydromechanical communication in Acartia tonsa. Mar Ecol Prog Ser 300:129-133

Berg HC (1993) Random walks in biology. Princeton University Press, Princeton, NJ

Blades PI (1977) Mating behaviour of Centropages typicus (Copepoda: Calanoida). Mar Biol 40:57-64

Boxshall GA (1998) Preface. Phil Trans R Soc Lond B 353: 669-670

Buskey EJ (1998) Components of mating behaviour in planktonic copepods. J Mar Syst 15:13-21

Csanady GT (1973) Turbulent diffusion in the environment. Reidel, Dordrecht

Castro P, Huber ME (2003) Marine biology, 4th edn. McGraw Hill, Boston, MA

Colin SP (1995) A kinematic analyis of trail-following in Temora longicornis and four other copepods: how the male finds his mate. MS thesis, State University of New York at Stony Brook

Decho AW, Browne KA, Zimmer-Faust RK (1998) Chemical cues: why basic peptides are signal molecules in marine environments. Limnol Oceanogr 43:1410-1417

Doall MH, Colin SP, Strickler JR, Yen J (1998) Locating a mate in 3D: the case of Temora longicornis. Phil Trans R Soc Lond B 353:681-689

Doall MH, Wilson SE, Strickler JR, Yen J (2001) The tandem hop mating dance of Acartia tonsa, a planktonic calanoid copepod. Abstract, Aquatic Science Meeting, Albuquerque. American Society of Limnology and Oceanography, Waco, TX

Dusenbery DB (1992) Sensory ecology. Freeman, New York

Frey MA, Lonsdale DJ, Snell TW (1998) The influence of contact chemical signals on mate recognition in a harpacticoid copepod. Phil Trans R Soc Lond B 353:745-751

Fryd M, Haslund OH, Wohlgemuth O (1991) Development, growth and egg production in the two copepod species Centropages hamatus and Centropages typicus in the laboratory. J Plankton Res 13:683-689

Gill CW, Poulet SA (1988) Response of copepods to dissolved free amino acids. Mar Ecol Prog Ser 43:269-276

Griffiths AM, Frost BW (1976) Chemical communication in the marine planktonic copepods Calanus pacificus and Pseudocalanus sp. Crustaceana 30:1-9

Holmes SJ (1903) Sex recognition in Cyclops. Biol Bull (Woods Hole) 5:313-315

Howlett R (1998) Sex and the single copepod. Nature 394: 423-425

Ikeda T, Kanno Y, Ozaki K, Shinada A (2001) Metabolic rates of epipelagic marine copepods as a function of body mass and temperature. Mar Biol 139:587-596

Jackson GA, Kiørboe T (2004) Finding a particle to eat by a chemosensitive zooplankter. Mar Ecol Prog Ser 269: 153-162

Jacobs J (1961) Laboratory cultivation of the marine copepod Pseudodiaptomus coronatus Williams. Limnol Oceanogr 6: 443-446

Jacoby CA, Youngbluth MJ (1983) Mating behaviour in three species of Pseudodiaptomus (Copepoda: Calanoida). Mar Biol 76:77-86

Katona S (1973) Evidence for sex pheromones in planktonic copepods. Limnol Oceanogr 18:574-583

Kelly LS, Snell TW (1998) Role of surface glycoproteins in mate-guarding of the marine harpacticoid Tigriopus japonicus. Mar Biol 130:605-612

Kelly LS, Snell TW, Lonsdale DJ (1998) Chemical com- 
munication during mating of the harpacticoid Tigriopus japonicus. Phil Trans R Soc Lond B 353:737-744

Kiørboe T (1993) Turbulence, phytoplankton cell size, and the structure of pelagic food webs. Adv Mar Biol 29:2-61

Kiørboe T (1997) Population regulation and role of mesozooplankton in shaping marine pelagic food webs. Hydrobiologia 363:13-27

Kiørboe T (2001) Formation and fate of marine snow: small scale processes with large scale implications. Sci Mar 65: $57-71$

Kiørboe T, Bagøien E (2005) Motility patterns and mate encounter rates in planktonic copepods. Limnol Oceanogr 50(6): in press

Kiørboe T, Thygesen UH (2001) Fluid motion and solute distribution around sinking aggregates. II. Implications for remote detection by colonizing zooplanktors. Mar Ecol Prog Ser 211:15-25

Kiørboe T, Møhlenberg F, Hamburger K (1985) Bioenergetics of the planktonic copepod Acartia tonsa: relation between feeding, egg production and respiration, and composition of specific dynamic action. Mar Ecol Prog Ser 26:85-97

Kiørboe T, Bagøien E, Thygesen U (2005) Blind dating — mate finding in planktonic copepods. II. The pheromone cloud of Pseudocalanus elongatus. Mar Ecol Prog Ser 300: $117-128$

Lazzaretto I, Franco F, Battaglia B (1994) Reproductive behaviour in the harpacticoíd copepod Tigriopus fulvus. Hydrobiologia 292/293:229-234

Lazzaretto I, Salvato B, Libertini A (1990) Evidence of chemical signalling in Tigriopus fulvus (Copepoda, Harpacticoida). Crustaceana 59:171-179

Lenz J (2000) Introduction. In: Harris RP, Wiebe PH, Lenz J, Skjoldal HR, Huntley M (eds) Zooplankton methodology manual. Academic, London, p 1-53

Lonsdale DJ, Frey MA, Snell JW (1998) The role of chemical signals in copepod reproduction. J Mar Syst 15:1-12

Nihongi A, Lovern SB, Strickler JR (2004) Mate-searching behaviors in the freshwater calanoid copepod Leptodiaptomus ashlandi. J Mar Syst 49:65-74

Okubo A (1980) Diffusion and ecological problems: mathematical models. Springer, Berlin

Parker GH (1902) The reactions of copepods to various stimuli and the bearing of this on daily depth migrations. Bull US Fish Comm 21:103-123

Poulet SA, Quellet G (1982) The role of amino acids in the chemosensory swarming and feeding of marine copepods. J Plankton Res 4:341-361

Editorial responsibility: Otto Kinne (Editor-in-Chief), Oldendorf/Luhe, Germany
Riffell JA, Krug PJ, Zimmer RK (2002) Fertilization in the sea: the chemical identity of an abalone sperm attractant. J Exp Biol 205:1439-1450

Roff JC (1972) Aspects of the reproductive biology of the planktonic copepod, Limnocalanus macrurus (Sars). Crustaceana 22:155-160

Snell TW, Carmona MJ (1994) Surface glycoproteins in copepods: potential signals for mate recognition. Hydrobiologia 292/293:255-264

Strickler JR (1998) Observing free-swimming copepods mating. Phil Trans R Soc Lond B 353:671-680

Thomson H, Ache BW (1980) Threshold determination for olfactory receptors of the spiny lobster. Mar Behav Physiol $7: 249-260$

Ting JH, Kelly LS, Snell TW (2000) Identification of sex, age and species-specific proteins on the surface of the harpacticoid copepod Tigriopus japonicus. Mar Biol 137: 31-37

Ting JH, Snell TW (2003) Purification and sequencing of a mate-recognition protein from the copepod Tigriopus japonicus. Mar Biol 143:1-8

Tsuda A, Miller CB (1998) Mate-finding behaviour in Calanus marshallae Frost. Phil Trans R Soc Lond B 353: 713-720

Uchima M, Hirano R (1988) Swimming behaviour of the marine copepod Oithona davisae: internal control and search for environment. Mar Biol 99:47-56

Uchima M, Murano M (1988) Mating behaviour of the marine copepod Oithona davisae. Mar Biol 99:39-45

van Leeuwen HC, Maly EJ (1991) Changes in the swimming behaviour of male Diaptomus leptopus (Copepoda:Calanoida) in response to gravid females. Limnol Oceanogr 36: 1188-1195

Visser AW, Jackson GA (2004) Characteristics of the chemical plume behind a sinking particle in turbulent water. Mar Ecol Prog Ser 283:55-71

Watras CJ (1983) Mate location by diaptomid copepods. J Plankton Res 5:417-425

Weissburg MJ, Doall MH, Yen J (1998) Following the invisible trail: Kinematic analysis of mate tracking in the copepod Temora longicornis. Phil Trans R Soc Lond B 353: 701-712

Wolf E (1905) Die Fortpflanzungverhältnisse unserer einheimischen Copepoden. Zool Jb Syst 22:101-280

Yen J, Weissburg MJ, Doall MH (1998) The fluid physics of signal perception by mate-tracking copepods. Phil Trans R Soc Lond B 353:787-804

Submitted: December 22, 2004; Accepted: May 17, 2005

Proofs received from author(s): August 26, 2005 